\title{
Er omsorg som er motivert av kjærlighet, bedre enn omsorg gitt av plikt?
}

Den mest oppofrende omsorgen er ikke nødvendigvis den mest bærekraftige. Omsorg som er avgrenset og verner om omsorgsyteren, kan være god omsorg, selv om kjærligheten mangler.

\section{Forfattere}

Signe Tretteteig

Prosjektkoordinator og redaktør

Nasjonal kompetansetjeneste for aldring og helse, Sykehuset i Vestfold

Kirsten Thorsen

Seniorforsker

Nasjonal kompetansetjeneste for aldring og helse, Sykehuset i Vestfold

$\begin{array}{llll}\text { Pårørende } \quad \text { Verdier } \quad \text { Demens } & \text { Mature Care Omsorgsfilosofi }\end{array}$

Sykepleien 2019 107(77691)(e-77691)

DOI: https://doi.org/10.4220/Sykepleiens.2019.77691

\section{Hovedbudskap}

Å gi omsorg og hjelp til foreldre er en frivillig oppgave basert blant annet på pårørendes ønske, evne og mulighet til å hjelpe. Som profesjonelle omsorgsarbeidere er vi opplært i en altruistisk omsorgstradisjon der omsorgsgiveren skal være barmhjertig og uselvisk og gi betingelsesløs omsorg. Pårørende kan bli slitne og utbrente, noe som kan påvirke deres mulighet til å gi omsorg preget av slike verdier. 
Mature care er en alternativ omsorgsfilosofi der omsorgsgiverens og den omsorgstrengendes behov, interesser og verdier er mer likestilt. Med utgangspunkt i to pårørendehistorier vil denne artikkelen belyse hvordan de altruistiske omsorgsverdiene, versus verdiene i mature care-filosofien, kan gi støtte til ulike verdier i pårørendes omsorg. Kan pårørendeomsorg uten kjærlighet være god omsorg?

Både som helse- og omsorgspersonell og som privatpersoner har mange av oss erfaring med pårørendeomsorg. I Norge sees eldreomsorgen på som et samfunnsansvar med familien i en supplerende rolle, og pårørende har ingen lovmessig omsorgsplikt for sine foreldre (1). Det å gi omsorg og hjelp til foreldre er derfor en frivillig oppgave basert blant annet på pårørendes ønske, evne og mulighet til å hjelpe.

Likevel bruker mange pårørende mye tid og krefter på å gi omsorg til sine nærmeste. En kartleggingsstudie fra 2015 viste at en person med demens bor $\mathrm{i}$ gjennomsnitt seks år med demenssykdommen i eget hjem, og 90 prosent fikk hjelp av pårørende (2).

\section{Plikt eller kjærlighet}

Pårørendeomsorg sparer samfunnet for store økonomiske utgifter, og vi kan anta at mange er glade for den hjelpen og omsorgen de får fra sine voksne barn - en omsorg som ikke nødvendigvis kan erstattes med formell omsorg.

\section{$\equiv$ «Spiller det noen rolle hvilke følelser, verdier eller idealer pårørendes omsorg bygger på?»}

Men spiller det noen rolle hvilke følelser, verdier eller idealer pårørendes omsorg bygger på? Gir kjærlighet som motivasjon bedre omsorg enn omsorg gitt av plikt?

Vi vil i denne artikkelen se på hvordan ulike verdier og relasjoner kan motivere pårørende til å gi omsorg, og diskutere ulike konsekvenser av dette. 


\section{Data}

Artikkelens datagrunnlag er hentet fra en casestudie gjort som en del av doktoravhandlingen The impact of day care designed for people with dementia on their family caregivers $(3,4)$.

Historiene om Britt og Stein bygger på tre individuelle dybdeintervjuer med hver av dem, foretatt over to år. Intervjuene og analysen er gjort med en narrativ tilnærming $(5,6)$.

\section{Britt}

Britt er 61 år og har en mor med demens. Hun har alltid vært nært knyttet til moren og vært morens støtte og nære samtalepartner gjennom livet. Da har morens problemer stått i sentrum, og hun har vært lite lydhør for Britts utfordringer.

Nå har moren fått demens og har behov for hjelp og omsorg. De er ofte hjemme hos Britt, der de gjør husarbeid sammen. Slik aktiviseres moren.

Etter hvert har moren blitt mer opptatt av Britt og hennes liv, noe datteren verdsetter. Britt har vært sykemeldt en periode, men er nå tilbake i jobb. Det gjør at hun har mindre tid til moren, noe som gir henne dårlig samvittighet.

\section{Krevende omsorg}

Hun har også fått en venn. «Denne vennen min gir meg veldig mye energi, fordi jeg plutselig gjør veldig mange hyggelige ting. Mamma gir jo ikke energi, hun tar energi. Og så tar jobben energi hele uken. ... Jeg får ikke ro, jeg får ikke slappet av, fordi jeg føler dette presset hele tiden.» Hun lever med følelsen av at hun hele tiden må besøke moren. 
Omsorgen ble så krevende at datteren tok kontakt med demensteamet: «Med en helt fantastisk dame, og den samtalen har hjulpet meg. Den gjør det lettere å distansere meg fra mamma, noe jeg var nødt til å gjøre, fordi jeg var nødt til å passe på meg også.»

\section{$\equiv$ «Hun er sint fordi deler av familien ikke stiller opp mer.»}

Britt har hovedomsorgen for moren blant søsknene og beskriver forholdet slik: «Vi er som et triangel. Vi er tre ytterpunkter.» De har ulike tolkninger av mor og av hennes omsorgsbehov, og hun er derfor sint fordi deler av familien ikke stiller opp mer.

\section{Stein}

Stein er 49 år og har en far med demens. Faren forsvant ut av familien da Stein var ungdom, og de har hatt lite kontakt gjennom mange år. Da faren fikk demens, forsvant både samboeren og vennene til faren. «Alle er jo vekk. ... Noen måtte jo hjelpe, og da er vi de nærmeste til å gjøre det.»

Faren bodde da alene i skogen, ble forvirret, fikk angst og begynte å ringe sønnen mye om natten. «Vi tok tak i det og hjalp han til å få hjelp.»

Etter et korttidsopphold på sykehjem fikk faren dagtilbud fire dager i uken. Da er han trøtt når han kommer hjem, og ringer aldri. De andre dagene er han ensom og «maser» på telefonen. Sønnen besøker faren ukentlig, på stadig kortere visitter, fordi faren blir sliten. Men han er glad for besøk.

\section{Drittjobb}

Sønnen beskriver omsorgen som «en nødvendighet, rett og slett. En føler det er en plikt». Om relasjonen til faren understreker han: «Vi har jo fått mer samvær på en måte, men det er ikke blitt noe nærmere.» 


\section{三 «Han trives ikke med omsorgsrollen og gleder seg aldri til å besøke faren.»}

Søsknene tar omsorgen som et «prosjekt», det går greit nå, og sønnen synes hjelpen er tilstrekkelig. Faren har utnevnt ham som «prosjektleder». Han sier: «Det er en drittjobb. Jeg er ikke noe god på det, kunne ikke ha blitt sykepleier, det ligger ikke for meg.» Medfølelsen med faren «er ikke noe mer enn jeg skulle hatt til andre som jeg kjenner godt».

Han trives ikke med omsorgsrollen og gleder seg aldri til å besøke faren. Søsknene har alltid hatt et nært forhold, og de samarbeider godt om å hjelpe faren. Sønnen sier: «Det er bare for å ha det godt med meg selv at jeg må gjøre den plikten. Jeg kunne vel gjerne har vært den foruten.»

\section{Omsorgens «edle» verdier}

Som helse- og omsorgspersonell står vi i en lang profesjonsetisk tradisjon, der medfølelse, barmhjertighet, tillit og ærlighet er sentrale verdier. Disse verdiene er et resultat av filosofisk tenkning og utvikling av teorier gjennom ulike tidsepoker (7).

\section{三 «Yrkesetiske retningslinjer foreligger selvfølgelig ikke for uformell, frivillig pårørendeomsorg.»}

Helse- og omsorgspersonell er forpliktet i sin rolle til å tenke, handle og prioritere i tråd med fagprofesjonens yrkesteori og etiske retningslinjer. For sykepleiere, helsefagarbeidere og leger er disse etiske retningslinjene preget av verdier som selvbestemmelse, tillit, respekt, ansvar, empati, fortrolighet og rettferdighet (8-10). Slike yrkesetiske retningslinjer foreligger selvfølgelig ikke for uformell, frivillig pårørendeomsorg. 
Som profesjonelle omsorgsarbeidere er vi opplært i en altruistisk omsorgstradisjon, der omsorgsgiveren skal være barmhjertig og uselvisk og gi betingelsesløs omsorg (11, 12, 17). Den altruistiske omsorgen forrykker balansen i relasjonen mellom den som gir omsorg, og den som får. Omsorgsgiveren skal ideelt sett sette egne behov til side og prioritere behovene hos den hjelpetrengende så lenge det er behov for det.

\section{Allmennmoral}

Ser vi litt ut over profesjonsetikken, betraktes nestekjærlighets- og barmhjertighetstanken som kjernen i omsorg, der omsorg er preget av en ekte og dyp vilje til å lindre den andres lidelse (13).

Omsorg omtales i tradisjonell omsorgsfilosofi som noe som alltid har vært til stede mennesker imellom, som noe basalt og opprinnelig ved det å være menneske. «Det er en uavviselig sannhet at både moralen og språket er på plass og i funksjon før vi er i det», skriver Tranøy (14, s. 40).

I ulike kulturer finnes det en «allmennmoral», som angir normer for omsorg i ulike relasjoner i det som betegnes som «vår felles hverdagsverden». En slik moral er retningsgivende for hvem vi skal gi omsorg, hvor langt vi skal strekke oss, og hvordan vi skal utvise omsorg.

\section{三 «Den uselviske omsorgsgiveren risikerer å bli en selvfornektende person.»}

I vårt humane fellesskap bygges omsorg på grunnleggende verdier som solidaritet, verdighet, medlidenhet, barmhjertighet og nestekjærlighet, og omsorgen knyttes til å tjene den andre i kjærlighet (15, 16). Men den uselviske omsorgsgiveren risikerer å bli en selvfornektende person, kun et middel til å tilfredsstille den andres behov. 
Mature care er en alternativ omsorgsfilosofi der omsorgsgiverens og den omsorgstrengendes behov, interesser og verdier er mer likestilt (17). Et sentralt element er hvordan omsorgsgiveren tar vare på seg selv, noe som anses som avgjørende for å kunne gi god omsorg.

Sammenlikner vi etikken i den «tradisjonelle omsorgen» med profesjonsetikken, ser vi at verdiene i stor grad er sammenfallende. Erfaring og mye forskning viser at pårørende kan bli slitne og utbrente (18). Dette kan påvirke deres mulighet til å gi omsorg preget av kjærlighet, barmhjertighet og en dyp vilje til å lindre den andres lidelse. Men kan pårørendeomsorg uten kjærlighet være god omsorg?

\section{Vektlegger relasjonen}

Til forskjell fra den altruistiske omsorgsfilosofien vektlegger mature care-filosofien likevekt i relasjonen mellom omsorgsgiver og den omsorgstrengende. Pettersen (17) tydeliggjør behovet for en slik likevekt, da hun mener at maktmisbruk i omsorgssituasjonen kan gå begge veier.

\section{三 «Omsorgsgivere kan oppleve at grenseløs omsorg skaper grunnlag for utbrenthet.»}

Hva hvis behovet for omsorg er bunnløst, kan

hjelperen da sette grenser som kan begrunnes etisk?

Hva hvis den syke utnytter omsorgsgiverens vilje til å hjelpe?

Og den andre veien: Hva hvis omsorgsgiveren utnytter situasjonen til å utøve kontroll og makt over den hjelpetrengende, eller har egne motiver, som å høste medlidenhet og beundring fra andre personer?

Pårørendeomsorg kan også foregå i relasjoner preget av vold, overgrep og misbruk. Omsorgsgivere kan oppleve at grenseløs omsorg skaper grunnlag for utbrenthet. 


\section{Gjensidig avhengighet}

Slike dilemmaer peker på behovet for en omsorgsfilosofi basert på moden omsorg, med vekt på lydhørhet, oppmerksomhet, likeverd og gjensidighet mellom partene. Begrepet «relasjonell autonomi» peker mot selvstendighet innen en gjensidig avhengighet. Begge parters behov skal vektlegges, om ikke nødvendigvis like mye.

Omsorg er noe som skjer i en relasjon mellom mennesker, den er en relasjonell aktivitet (17). Familiehistorie og familierelasjoner vil legge grunnlaget for følelser og innhold i omsorgen, bærekraften i omsorgen, hvor mye og hvor lenge den varer, samt samspillet mellom familiemedlemmer.

Forskning viser at eldre foreldre har et ønske om å være uavhengige av sine barn og er tilbakeholdne med å forvente hjelp fra dem (19). På tross av godt utbygde helse- og velferdstjenester for eldre i Norge har samfunnet en klar norm om å yte pårørendeomsorg. Hjelpen og omsorgen er differensiert etter typer tjenester og oppgaver, der pårørendeomsorgen utfyller den offentlige omsorgen.

\section{Er Britts og Steins omsorg personsentrert?}

Personsentrert omsorg er i dag en retningsgivende omsorgsfilosofi for demensomsorgen i Norge (20). Grunnleggende i denne omsorgsfilosofien er at omsorg og aktiviteter skal være individuelt tilpasset og dekke behovene til personen med demens. Det gjelder spesielt behov for inklusjon, identitet, tilhørighet, beskjeftigelse og trøst.

\section{$\equiv$ «Omsorg og aktiviteter skal være individuelt tilpasset og dekke behovene til personen med demens.»}


I sentrum for disse verdiene står behovet for

kjærlighet, en kjærlighet som er generøs, tilgivende og ubetinget aksepterende, og som ikke ber om noe tilbake (21, 22). Å vise en slik kjærlighet er ikke like naturlig for alle. Brooker (22) mener at det å avdekke personens behov og dekke disse da er en måte å bevare personens personverd på.

\section{Altruisme eller plikt}

Umiddelbart kan det se ut som at Britts motivasjon til å gi moren omsorg er forankret i altruistiske verdier som medfølelse og nestekjærlighet, mens Steins motivasjon handler om å «gjøre sin plikt» uten å bli følelsesmessig engasjert. Men er Britts omsorg mer personsentrert enn Steins?

Steins omsorg er basert på farens behov for praktisk hjelp og kontakt. Han understreker at en sentral del av hjelpen har vært å skaffe faren offentlig hjelp. Faren fikk raskt dagaktivitetstilbud, noe som var til god støtte for både faren og sønnen.

\section{Kulturelle normer om pårørendeomsorg}

Sønnen gir faren omsorg selv om han gjentatte ganger poengterer at han ikke er glad i ham - omsorgen er uten kjærlighet som motivasjon. Hans familiære pliktetikk formuleres tydelig, men omsorgen har klare grenser både i forhold til faren og til seg selv.

\section{三 «Han ville hatt dårlig samvittighet om han ikke stilte opp.»}

Han er ikke følelsesmessig «overbelastet», han har ikke dårlig samvittighet og synes han gjør nok. Han ville hatt dårlig samvittighet om han ikke stilte opp. 
De kulturelle normene om pårørendeomsorg ser ut til å være sterke. Omsorgen er likevel personsentrert i den forstand at den tar utgangspunkt i farens behov. Omsorgen er også en del av en «omsorgshelhet», der han, søsknene og den offentlige omsorgen utfyller hverandre som tannhjul i et større «omsorgsverk».

Sønnen reflekterer over den følelsesmessige avstanden til faren: «Det er kanskje lettere for meg å gjøre det? ... Altså hvis det hadde skjedd med et annet menneske, for eksempel kona mi, så hadde det jo vært forferdelig. Så det er lettere kanskje, når en ikke har så nært forhold. ...

Det er nesten sånn at jeg er glad for at vi ikke har et så nært forhold nå som det har blitt sånn som det er. For det er rett og slett enklere å forholde seg til når du har litt avstand. Å prøve å gjøre en ordentlig jobb.»

\section{Følelsene tar overhånd}

For Britt har kjærlighet og et ønske om å være nær moren stor plass når hun snakker om omsorgen til moren. Hun utbryter plutselig: «Gud, så mange ord jeg har om dette!» Hennes fortelling er omtrent dobbelt så lang som Steins, og er fylt av nyanser og detaljer om følelser, relasjoner og hendelser plassert i hverdagslivet.

\section{三 «Hun må få hjelp til å sette grenser for omsorgen og ta hensyn til seg selv.»}

Men følelsene i omsorgen tar overhånd og blir for mye for henne. Hun gir mye omsorg, men føler likevel en stor, voksende og utmattende dårlig samvittighet. Hun må få hjelp til å sette grenser for omsorgen og ta hensyn til seg selv. 
Den «grenseløse» omsorgsforpliktelsen og oppofrelsen har også en bakside: sinnet mot familiemedlemmer som ikke gjør like mye som henne. På slutten av siste intervju har hun denne erkjennelsen: «Det handler jo om å gi seg selv tillatelsen til å ikke ha dårlig samvittighet. ... Det er jo ingen som presser meg, det er meg selv som gjør det.»

\section{Forelderens verdsettelse}

Ser vi på Kitwoods filosofi, ser det ut som at Britt gir moren kjærlighet, beskjeftigelse og tilhørighet gjennom samvær og den emosjonelle nærheten hun gir og får.

Men heller ikke Britts omsorg gis ubetinget og premissløs. Det kan se ut som at hennes motivasjon også er preget av et behov for å være «den gode datteren» og den «favoriserte datteren». Det er ingen tvil om at Britt er oppriktig i sin kjærlighet, men kjærligheten er ikke nødvendigvis altruistisk i betydningen uselvisk, da den i stor grad er preget av hennes egne behov.

Britt trenger morens verdsettelse for å føle seg som en god omsorgsgiver. Stein klarer seg uten farens verdsettelse, fordi omsorgen er et prosjekt og en plikt. Han sier i ettertanke: «For vi har jo hørt om gamle par der den ene har blitt dement, og de sliter jo voldsomt. Og det gjør jo ikke vi, ingen av ungene. Vi sliter ikke med det i det hele tatt!»

\section{Konklusjon}

Den mest emosjonelle, oppofrende og kjærlighetsfylte omsorgen fra barn til foreldre med demens behøver ikke være den mest bærekraftige - eller den beste omsorgen over tid. Den kan være utmattende, overbelastende og helsenedbrytende. En moden omsorg, som er avgrenset og verner om omsorgsyteren, kan være god omsorg, selv om kjærligheten mangler. 
Utmattende omsorg sliter på kjærligheten og

relasjonen. God pårørendeomsorg kan være å overlate

omsorgen til det offentlige.

\section{三 «En moden omsorg kan være god omsorg, selv om kjærligheten mangler.»}

Krevende privat omsorg er som regel ikke enten drevet av plikt eller (neste)kjærlighet, den er gjerne både og, blandet, ambivalent, preget av plikt, ansvar, forholdets historie og både givers og mottakers behov. Den er med andre ord kompleks og kontekstavhengig.

God helhetlig personsentrert omsorg skjer i et lydhørt samarbeid med de pårørende. Lytt til dem og aksepter deres omsorgsverdier! De er grunnfjellet i omsorgen.

\section{Referanser}

1. Helsedirektoratet. Veileder om pårørende i helse- og omsorgstjenesten. Oslo: Helsedirektoratet; 2017. IS-2587. Tilgjengelig fra:

https://www.helsedirektoratet.no/veiledere/parorendev eileder (nedlastet 27.06.2019).

2. Vossius C, Selbæk G, Ydstebø AE, Benth JS, Godager G, Lurås H, et al. Ressursbruk og sykdomsforløp ved demens (REDIC) kortversjon.

Ottestad: Alderspsykiatrisk forskningssenter Sykehuset Innlandet, Regionalt kompetansesenter for eldremedisin og samhandling i Helse Vest (SESAM); 2015.

3. Tretteteig S. The impact of day care designed for persons with dementia on their family caregivers. (Doktoravhandling.) Oslo: Universitetet i Oslo; 2017. 
4. Tretteteig S, Vatne S, Rokstad AMM. Meaning in family caregiving for people with dementia: a narrative study about relationships, values, and motivation, and how day care influences these factors. Journal of multidisciplinary healthcare. 2017;10:44555.

5. Geertz C. The interpretation of cultures. New York: Basic Books; 1973.

6. Flyvbjerg B. Five misunderstandings about case-study research. Qualitative Inquiry. 2006;12(2):219-45.

7. Eide SB, Grelland HH, Kristiansen A, Sævareid HI, Aasland GG. Fordi vi er mennesker. En bok om samarbeidets etikk. Bergen: Fagbokforlaget; 2003.

8. Norsk Sykepleierforbund. Yrkesetiske retningslinjer for sykepleiere. Oslo: Norsk Sykepleierforbund; 2019. Tilgjengelig fra: https://www.nsf.no/visartikkel/2193841/17102/Yrkesetiske-retningslinjer (nedlastet 27.05.2019).

9. Helsefagarbeidere i Delta. Yrkesetiske retningslinjer for helsefagarbeidere. Helsefagarbeidere i Delta; 2018. Tilgjengelig fra:

https://delta.no/yrke/helsefagarbeidere-idelta/yrkesetiske-retningslinjer-for-helsefagarbeiderei-delta (nedlastet 27.05.2019).

10. Den norske legeforening. Etiske regler for leger. Oslo: Den norske legeforening; 2015. Tilgjengelig fra: https://beta.legeforeningen.no/omoss/Styrende-dokumenter/legeforeningens-lover-ogandre-organisatoriske-regler/etiske-regler-forleger/\#23667 (nedlastet 27.05.2019). 
11. Martinsen K, Alvsvåg H, Torsteinson IO. Den omtenksomme sykepleier: artikkelsamling i forbindelse med at Diakonissehjemmets sykepleierhøgskole Haraldsplass er 75 år i mai 1993. Oslo: Tano; 1993.

12. Løgstrup K. Den etiske fordring. Oslo:

Cappelen; 1999.

13. Lindström UÅ, Lindholm L, Zetterlund JE, Eriksson K. Theory of caritative caring. I: Tomey AMA, red. Nursing theorists and their work. 6. utg. St. Louis: Elsevier Mosby; 2006. s. 191-223.

14. Tranøy KE. Det åpne sinn. Moral og etikk mot et nytt årtusen. Oslo: Universitetsforlaget; 1998.

15. Eriksson K. Vårdandets idéhistoria. Vårdandets och vårdvetenskapens idéhistoria. Strövtåg i spårandet av «caritas originalis». Vårdforskning Institutionen för vårdvetenskap, Åbo Akademi. 2002;8:14-33.

16. Nåden D, Foss B, Sæteren B. Omsorgens betydning og uttrykk i en klassisk tekst. Tidsskrift for omsorgsforskning. 2018;4(3):241-52.

17. Pettersen T. Conceptions of care: altruism, feminism, and mature care. Hypatia. 2012;27(2):36689.

18. Thyrian JR, Winter P, Eichler T, Reimann M, Wucherer D, Dreier A, et al. Relatives' burden of caring for people screened positive for dementia in primary care: results of the DelpHi study. Zeitschrift für Gerontologie und Geriatrie. 2016;50(1):4-13.

19. Daatland SO, Veenstra M, Lima I. Helse, familie og omsorg over livsløpet. Resultater fra LOGG og NorLag. Oslo: Norsk institutt for forskning om oppvekst, velferd og aldring; 2009. 
20. Helsedirektoratet. Nasjonal retningslinje for demens. Oslo: Helsedirektoratet; 2017.

21. Kitwood T, Høeg D, Johnsen N. En revurdering af demens: personen kommer i første række. Frederikshavn: Dafolo; 1999.

22. Brooker D. Personsentrert demensomsorg: veien til bedre tjenester. Tønsberg: Forlaget Aldring og helse; 2013. 